\title{
ПРОЦЕСУАЛЬНІ АСПЕКТИ ЗАЛУЧЕННЯ СПЕЦІАЛІСТІВ ДОСЛІДНО-ВИПРОБУВАЛЬНИХ ЛАБОРАТОРІЙ ТЕРИТОРІАЛЬНИХ ОРГАНІВ ДСНС ДО УЧАСТІ В ОГЛЯДІ МІСЦЯ ПОДІї, ПОВ'ЯЗАНОЇ З ПОЖЕЖЕЮ
}

Середа Д. В., Климась Р. В.

У статmі розглянуто організаційні аспекти залучення органами досудового розслідування спеціалістів дослідно-випробувальних лабораторій територіальних органів ДСНС під час проведення огляду місця події, пов'язаної з пожежею. Наведено основні принципи їх взаємодіі. Зроблено висновок, що робота щодо вдосконалення взаємодіі слідчого та спеціаліста дослідно-випробувальної лабораторії територіального органу Державної служби України з надзвичайних ситуацій на стадії огляду місця пожежі потребує подальшого вдосконалення.

Ключові слова: дослідно-випробувальна лабораторія, огляд місця пожежі, орган досудового розслідування, спеціаліст.

В статье рассмотрены организационные аспекты привлечения органами досудебного расследования специалистов исследовательско-испытательных лабораторий территориальных органов Государственной службы Украины по чрезвычайных ситуациям при проведении осмотра места происшествия, связанного с пожаром. Приведены основные принципы их взаимодействия. Сделано вывод, что работа по взаимодействию следователя и специалиста исследовательско-испытательной лаборатории территориальных органов Государственной службы Украины по чрезвычайных ситуациям на стадии осмотра места пожара требует дальнейшего улучшения.

Ключевые слова: исследовательско-испытательная лаборатория, осмотр места пожара, орган досудебного расследования, специалист.

Sereda D. V., Klymas R. V. Procedural aspects of involvement of specialists of experimental and testing laboratories of territorial bodies of the State Service of Ukraine for Emergency Situations to participate in the consideration of the body

The article considers the organizational aspects of the involvement of pre-trial investigation specialists of the experimental testing laboratories of the territorial bodies of the State Service of Ukraine for Emergency Situations during the inspection of the scene related to the fire. The basic principles of their interaction are given, which, depending on the legal regulation, are divided into procedural (legal) and non-procedural (organizational). Having studied the practice of investigating criminal offenses related to fires, the pre-trial investigation identified two procedural forms of using special knowledge, namely the participation of a specialist of research laboratories of territorial State Service of Ukraine for Emergency Situations bodies in inspecting the fire site and involving an expert in fire technical examination. An obstacle to ensuring a proper inspection of the scene of a fire is the legal situation in which a fire specialist is involved in inspecting the scene of a fire related to a criminal offense, not necessarily, but only at the discretion of the investigator. On the improper organization of work on the interaction of investigators specializing in the investigation of criminal offenses committed by explosions and arson (fires) of the National Police investigators with specialists of research laboratories of territorial bodies of the State Service of Ukraine for Emergency Situations showed analysis of research laboratories of territorial bodies of the State Service of Ukraine for Emergency Situations in 2019 year. The peculiarity of the interaction between the investigator and the specialist testing laboratories of the territorial bodies of the State Service of Ukraine for Emergency Situations at the initial stage of the pre-trial investigation is the order of their mutual actions, which are directly related to detecting, fixing and removing traces and material evidence. At the same time, their interaction is a mutually agreed, joint, purposeful, qualified activity based on laws and regulations, organized at the appropriate level, aimed at fulfilling the tasks of criminal justice, the leading and organizing role of which belongs to the investigator, because it is the pre-trial investigation body is obliged to take all measures provided by law to ensure the effectiveness of the pre-trial investigation.

Key words: Research and testing laboratory, fire scene inspection, pre-trial investigation body, specialist.

Постановка проблеми та іï актуальність. Правову основу взаємодії органів досудового розслідування з територіальними органами Державної служби 3 надзвичайних ситуацій (далі - ДСНС) становлять Конституція України, Кримінальний та Кримінальний процесуальний кодекси України, закони України, акти Президента України, Кабінету Міністрів України, рішення Конституційного Суду України, міжнародні договори, згода на обов'язковість яких дана Верховною Радою України, і нормативно-правові акти Міністерства внутрішніх справ України з питань організації взаємодії між органами та підрозділами внутрішніх справ під час попередження, виявлення й розслідування кримінальних правопорушень.

3 набранням чинності у листопаді 2012 року Кримінального процесуального кодексу України (далі - КПК України) [1] змінився порядок залучення спеціалістів ДСНС, зокрема співробітників дослідно-випробувальних лабораторій Головних управлінь ДСНС в областях і місті Києві (далі - ДВЛ), до дослідження пожеж. Так, аналіз діяльності ДВЛ за напрямом дослідження пожеж, починаючи з 2013 року, свідчить про поступове зниження абсолютної кількості досліджених пожеж спеціалістами ДВЛ.

Аналіз останніх досліджень і публікацій. Окремі аспекти залучення спеціалістів до розслідування кримінальних правопорушень висвітлювали у своїх працях В.О. Коновалова [2, с. 401], А.М. Лазебний [3, с. 7-8], 
І.В. Пиріг [4, С. 260-262], В.О. Яремчук [5, с. 231] та інші. Але процес залучення спеціаліста ДВЛ до участі в проведенні огляду місця події, що пов'язана з пожежею, у вітчизняній криміналістиці досі не розкрито.

Метою статті $\epsilon$ висвітлення організаційних аспектів залучення спеціалістів ДВЛ до участі в проведенні огляду місця події, пов'язаної з пожежею.

Виклад основного матеріалу. Відповідно до ч. 2 ст. 38 КПК досудове розслідування здійснюють слідчі органу досудового розслідування одноособово або слідчою групою. Тією ж статтею КПК визначено перелік органів досудового розслідування, до яких входять слідчі підрозділи: органів Національної поліції; органів безпеки; органів, що здійснюють контроль за додержанням податкового законодавства, та органів Державного бюро розслідувань, а також підрозділи детективів, підрозділ внутрішнього контролю Національного антикорупційного бюро України. Таким чином, кримінальні правопорушення, пов'язані з пожежами, розслідуються слідчими Національної поліції України (далі - поліція). 3 метою всебічного, повного і неупередженого дослідження обставин кримінального правопорушення органи (підрозділи) поліції можуть залучати для встановлення причин виникнення пожеж, а також обставин та умов, що сприяли їх виникненню, територіальні органи ДСНС.

Підрозділом ДСНС, що спеціалізується в питаннях дослідження пожеж, $є$ ДВЛ. Одним з основних завдань, відповідно до документів [6, с. 1,7, с. 1], що регламентують їхню діяльність, є саме дослідження пожеж. Під час проведення таких досліджень встановлюється осередки пожеж, джерела та технічні причини їх виникнення, визначаються умови й обставини, що сприяли виникненню горіння та його розвитку i спричинили тяжкі наслідки, поведінку будівельних конструкцій, виробів і матеріалів під час пожежі.

Основними принципами взаємодії $\epsilon$ [8]:

1) швидке, повне та неупереджене розслідування кримінальних правопорушень;

2) самостійність слідчого в процесуальній діяльності, втручання в яку осіб, що не мають на те законних повноважень, забороняється;

3) оптимальне використання наявних можливостей органів досудового розслідування та оперативних підрозділів Національної поліції України у запобіганні, виявленні та розслідуванні кримінальних правопорушень;

4) дотримання загальних засад кримінального провадження;

5) забезпечення нерозголошення даних досудового розслідування.

Дослідивши існуючі в науці фабули щодо розподілу форм взаємодії для використання спеціальних знань у процесі розслідування, можна розділити їх на процесуальні та непроцесуальні. До процесуальних належить, зокрема, залучення спеціаліста для участі в проведенні слідчих дій (ст. 71 КПК). Взаємодія слідчих з обізнаними особами, які набувають процесуального статусу спеціаліста під час провадження слідчих дій, виражається в безпосередній практичній, методичній і технічній діяльності непідпорядкованих в адміністративному порядку суб'єктів для вирішення конкретних завдань розслідування. Процесуальні питання співпраці слідчого зі спеціалістами в законодавчому аспекті потребують удосконалення.
До непроцесуальних форм взаємодії слідчого зі спеціалістами потрібно віднести: консультації у вигляді усних роз'яснень, порад, письмових довідок, актів зі спеціальних питань тощо; проведення попередніх досліджень за запитом слідчого, що оформляються довідкою-актом, які можуть розглядатися як інші документи в провадженні; взаємний обмін інформацією та спільні обговорення зібраних у провадженні доказів, висунення обґрунтованих версій і визначення шляхів їх роз'яснення [9, с. 15-16].

На практиці розслідування кримінальних правопорушень, пов'язаних із пожежами, на досудовому розслідуванні розрізняють дві процесуальні форми використання спеціальних знань: участь спеціаліста ДВЛ у проведенні огляду місця пожежі та залучення експерта до проведення пожежно-технічної експертизи.

Спеціалістом у кримінальному провадженні відповідно до ч. 1 ст. 71 КПК України «є особа, яка володіє спеціальними знаннями та навичками застосування технічних або інших засобів і може надавати консультації під час досудового розслідування і судового розгляду з питань, що потребують відповідних спеціальних знань і навичок» [1]. Таким чином, співробітник ДВЛ під час дослідження пожежі виступає як спеціаліст, керується всіма правами, наданими йому, а також виконує певний обсяг обов'язків.

Водночас ч. 2 ст. 71 КПК України передбачено, що «спеціаліст може бути залучений для надання безпосередньої технічної допомоги (фотографування, складення схем, планів, креслень, відбір зразків для проведення експертизи тощо) сторонами кримінального провадження під час досудового розслідування і судом під час судового розгляду» [1].

Чинне формулювання сукупності положень ч. 3 ст. 17, ст. 40, п. 2 ст. 71, ч. 3 ст. 237 КПК України, на думку авторів, створює правову ситуацію, за якої спеціаліст із дослідження пожеж залучається до огляду місця пожежі, пов'язаної з кримінальним правопорушенням, не в обов'язковому порядку, а лише за рішенням слідчого (на його розсуд). Це у свою чергу стає перепоною гарантії забезпечення належного огляду місця пожежі, враховуючи те, що не кожен слідчий може належним чином (без допомоги спеціаліста) оглянути місце події (пожежі), виявити, зафіксувати та вилучити сліди, предмети та матеріали, що в подальшому набудуть у процесуальному порядку статус доказів.

Необізнаній в юридичному плані особі буде складно трактувати можливість (необхідність) участі спеціаліста ДВЛ у слідчій дії через запрошення слідчим на огляд місця події чи для іншої слідчої дії через вивчення класифікації учасників кримінального провадження на певні сторони кримінального провадження (ст. 17 КПК); тобто для того щоб зрозуміти, хто саме може, виступаючи стороною кримінального провадження, запросити спеціаліста, треба застосовувати ст. 17 КПК України, що $€$ недоречним, нелогічним і незручним. Крім того, саме у п. 2 ст. 71 КПК України «Спеціаліст» посилання на ст. 17 КПК України відсутнє.

Враховуючи вищевикладене, слід зазначити, що особливостями взаємодії слідчого та спеціаліста ДВЛ на початковому етапі досудового розслідування $\epsilon$ порядок (алгоритм) їх взаємних дій, які безпосередньо пов'язані з виявленням, закріпленням та вилученням слідів і речових доказів, відповідно до тактики огляду місця події та методики розслідування пожеж [10, с. 33-40]. 
Єдиним натепер нормативно-правовим актом, в якому визначено порядок взаємодії слідчого зі спеціалістами ДВЛ під час проведення огляду місця пожежі, $€$ Порядок спільних дій Національної поліції України, Державної служби України з надзвичайних ситуацій та Експертної служби Міністерства внутрішніх справ України під час проведення огляду місця пожежі, виявлення, припинення попередження та розслідування кримінальних правопорушень та інших подій, пов'язаних з пожежами [11, с 1], відповідно до якого на місце події, пов'язаної з пожежею (вибухом), виїжджає слідчо-оперативна група у складі слідчого, працівників оперативного підрозділу та спеціалістів. Як спеціалісти залучається зазвичай інженерно-інспекторський склад територіальних органів ДСНС України. Разом із тим відповідно до вимог [11, с. 14] до складу слідчо-оперативної групи у випадках проведення огляду місця пожежі, в разі якщо внаслідок пожежі загинуло три і більше або постраждало 5 і більше осіб; сталася пожежа із загибеллю або травмуванням людей на підприємствах, установах, в організаціях, закладах; площа пожежі становить 1000 та більше метрів квадратних; орієнтовні збитки внаслідок пожежі становлять 10 тисяч і більше неоподатковуваних мінімумів доходів громадян, в обов'язковому порядку для фіксації обстановки на місці пожежі, проведення пожежно-технічних досліджень (експертизи) та встановлення обставин і причин виникнення пожежі залучається посадова особа ДВЛ. Також спеціалісти ДВЛ можуть залучатися до участі в проведенні огляду місця пожежі за рішенням слідчого, якщо наявна інша необхідність.

У результаті аналізу діяльності ДВЛ за напрямом дослідження пожеж за 2019 рік з'ясовано, що спеціалістами лабораторій було взято участь у дослідженні 1589 пожеж, із них лише п'ята частина була досліджена за рішенням слідчого. Дана статистика свідчить про неналежну організацію роботи із взаємодії слідчих, які спеціалізуються на розслідуванні кримінальних правопорушень, скоєних шляхом вибухів і підпалів (пожеж), слідчих органів Національної поліції зі спеціалістами ДВЛ, що не сприяє виявленню всіх обставин та причин виникнення пожеж, пов'язаних із кримінальним правопорушенням. Разом із тим знання спеціалістів ДВЛ допомагають всебічно, повно і неупереджено дослідити обставини кримінального провадження, виявити як ті обставини, що підтверджують, так і ті, що спростовують версію щодо ймовірної причини виникнення пожежі.

Висновки. Взаємодія слідчого зі співробітниками територіальних органів ДСНС України, зокрема спеціалістами ДВЛ, під час досудового розслідування - це взаємоузгоджена, спільна, цілеспрямована, кваліфікована діяльність, заснована на законах і нормативно-правових актах, організована на належному рівні та спрямована на виконання завдань кримінального судочинства. Керівна та організуюча роль у цій взаємодії належить слідчому, оскільки саме на орган досудового розслідування покладається обов'язок вживати всі передбачені законом заходи для забезпечення ефективності досудового розслідування. Початок взаємодії, як правило, ініціює слідчий. Робота щодо вдосконалення взаємодії слідчого та спеціаліста ДВЛ на стадії огляду місця пожежі потребує подальшого вдосконалення.

\section{Література}

1. Кодекс України про адміністративні порушення від 07 грудня 1984 р. № 8073-Х. Відомості Верховної Ради Української РСР (ВВР). 1984. Додаток до № 51. Ст. 1122. URL: https: / /zakon.rada.gov.ua/laws/show/4651-17\#Text

2. Коновалова В.Е. Криминалистические проблемы борьбы с убийствами по заказу, совершаемыми организованными группами. Вибрані твори. Харків : Апостіль, 2012. Глава 6. С. 390-406.

3. Лазебний А.М. Використання спеціальних знань при розслідуванні кримінальних правопорушень проти громадського порядку : автореф. дис. ... канд. юрид. наук. Ірпінь, 2016. 19 с.

4. Пиріг І.В. Теоретико-прикладні проблеми експертного забезпечення досудового розслідування : монографія. Дніпропетровськ : Ліра ЛТД, 2015. 432 с.

5. Яремчук В.О. Взаємодія слідчого та спеціаліста під час слідчих (розшукових) дій. Науковий вісник Херсонського державного університету. 2016. Вип. 5.

6. Наказ Держтехногенбезпеки Про затвердження примірного Положення про дослідно-випробувальну лабораторію територіального органу Держтехногенбезпеки України від 18 травня 2012 року № 133.

7. Наказ МНС України Про затвердження Настанови з організації діяльності дослідно-випробувальної лабораторії Головного управління (управління) МНС України в області та м. Києві від 15 травня 2006 року № 289.

8. Наказ МВС від 07 липня 2017 № 575, «Про затвердження Інструкції з організації взаємодії органів досудового розслідування з іншими органами та підрозділами Національної поліції України в запобіганні кримінальним правопорушенням, їх виявленні та розслідуванні» зареєстрований в Міністерстві юстиції України 31 липня 2017 p. за № 937/30805. URL: https://zakon.rada.gov.ua/ laws/show/z0937-17\#Text

9. Ковальов В.В. Взаємодія слідчого з працівниками експертної служби МВС України : автореф. дис. ... на здобуття наук. ступеня канд. юрид. наук : 12.00.09 «Кримінальний процес та криміналістика ; судова експертиза». Київ, 2008. 20 с.

10. Дослідження пожеж. : довідково-методичний посібник. Київ : Пожінформтехніка, 1999. 224 с.

11. Наказ МВС України від 24 липня 2017 р. № 621 «Про затвердження Порядку спільних дій Національної поліції України, Державної служби України з надзвичайних ситуацій та Експертної служби Міністерства внутрішніх справ України під час проведення огляду місця пожежі, виявлення, припинення попередження та розслідування кримінальних правопорушень та інших подій, пов'язаних з пожежами", зареєстрованого в Міністерстві юстиції України 14 серпня 2017 р. № 998/30866.

Середа Д. В., науковий співробітник відділу досліджень, статистики пожеж та надзвичайних ситуацій науково-дослідного центру протипожежного захисту Iнституту державного управління та наукової діяльності з цивільного захисту

Климась Р. В., начальник відділу досліджень, статистики пожеж та надзвичайних ситуацій науково-дослідного центру протипожежного захисту Iнституту державного управління та наукової діяльності з цивільного захисту 